\title{
Matematik Öğretiminde Ters Yüz Öğrenme Modelinin Ortaokul Öğrencilerin Derse Katılımına Etkisi
}

\section{The Effect of Flipped Learning Model on Middle School Students' Classroom Engagement in Teaching Mathematics}

\section{Deniz KAYA*}

\begin{abstract}
Öz. Bu çalışmanın amacı, matematik öğretiminde ters yüz öğrenme modelinin ortaokul öğrencilerin derse katılımına etkisini incelemektir. Yarı deneysel desenin benimsendiği çalışmaya, $18^{\prime} \mathrm{i}$ deney ve $18^{\prime} \mathrm{i}$ kontrol grubunda olmak üzere toplam 36 sekizinci sınıf öğrencisi katılmışıı. Veri toplama aracı olarak, Derse Katılım Envanteri kullanılmıştır. Deneysel çalışma pilot uygulama dışında 6 hafta süreyle gerçekleştirilmiştir. Okulistik öğrenme platformundan temin edilen ders kazanımlarına uygun videolar Edpuzzle platformuna yüklenerek etkileşimli hale getirilmiştir. Verilerin analizinde, betimsel istatistiksel tekniklerin yanı sıra normallik analizleri, bağımsız örneklemler t-Testi, Mann-Whitney $U$ ve Wilcoxon İşaretli Sıralar testi kullanılmıştır. Uygulama sonucunda deney grubunun duyuşsal, davranışsal (uyma/itaat-sınıf katılımı), bilişsel katılım ile derse katılmama puanları kontrol grubundan anlamlı şekilde yüksek bulunmuştur. Deney grubunun derse katılım envanterinin tüm alt boyutlarına ait ön-test ile son-test puanları arasında anlamlı bir fark varken kontrol grubunun davranışsal (uyma/itaat) boyutu dışında anlamlı bir farka rastlanılmamıştır. Sonuç olarak, ters yüz öğrenme modelinin matematik öğretiminde kullanılmasının derse katılıma olumlu etkileri olduğu belirlenmiştir. Modelin farklı öğretim kademelerinde de etkinliğinin araştırılması öneri olarak sunulmuştur.
\end{abstract}

Anahtar Kelimeler: Derse katılım, ters yüz öğrenme, matematik öğretimi.

\begin{abstract}
The aim of this study is to investigate the effect of the flipped learning model on middle school students' classroom engagement in teaching mathematics. A total of 36 eighth grade students, 18 in control group and 18 in experimental group, participated in the study, in which the quasi-experimental design was used. Classroom Engagement Inventory was used as a data collection tool. An experimental study was carried out for 6 weeks except for pilot application. The videos which are suitable for the lesson acquisition obtained from the Okulistik learning platform have been uploaded to the Edpuzzle platform and made interactive. In the analysis of the data, a descriptive statistical technique as well as normality analyzes, independent samples t-Test, Mann-Whitney $U$ and Wilcoxon Signed Rank tests were performed. As a result of the application, the experimental group was significantly higher than the control group in terms of effective, behavioral (compliance/effortful classroom participation), cognitive engagement, and disengagement. There was a significant difference between pre-test and posttest scores of all sub-dimensions of the classroom engagement inventory of the experimental group but no significant difference except behavioral (compliance) dimension of the control group. As a result, it was determined that the use of the flipped learning model in mathematics teaching had positive effects on classroom engagement. It has been suggested that the model should be investigated in different teaching stages.
\end{abstract}

Keywords: Classroom engagement, flipped learning, mathematics teaching.

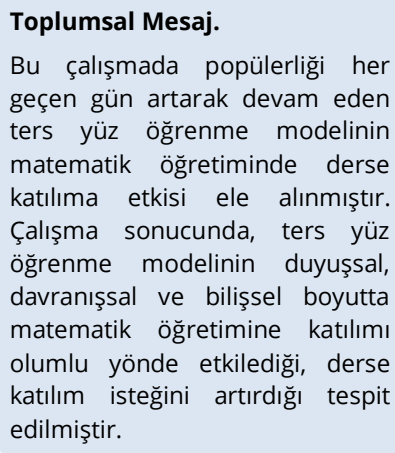

\section{Public Interest Statement.}

In this study, the effect of the flipped learning model, which has been increasing day by day on classroom engagement in the mathematics teaching, has been studied. As a result of the study, it was found that the flipped learning model positively effects engagement in teaching mathematics in affective, behavioral and cognitive dimensions, and increased the willingness to participate in the course.

\footnotetext{
* Orcid ID: https://orcid.org/0000-0002-7804-1772, Dr., Milli Eğitim Bakanlığı, denizkaya38@gmail.com 


\section{GíRiş}

Hiç şüphesiz, ülkelerin gelişmişlik düzeyinin en önemli göstergesi eğitimde elde ettiği başarıyla yakından ilgilidir. Bu bilince sahip çok sayıdaki ülkenin eğitim politikacısı öğretim sistemlerini gelişen ve değişen dünya dinamiklerine göre sistematik olarak dizayn etmektedir. Özellikle teknolojik ve bilimsel gelişmelerin önlenemez yükselişiyle birlikte öğrencilere olan bakış açısı hızlı bir değişime uğramıştır. Bireylerin bilgiye ulaşma ve iletişim kanallarının çeşitliliği bu değişimin en önemli sebepleri arasında yerini almıştır. Bilim ve teknoloji alanında yaşanan bu hızlı değişimin etkisini hissettirdiği alanlardan birisi de eğitim olmuştur. Dolayısıyla bilişim çağı çocuklarının daha nitelikli bir eğitim alabilmesi amacıyla teknolojinin eğitime entegrasyonu kaçınılmaz bir hal almış ve etkili kullanımı konusunda sürekli bir arayış içine girilmiştir. Bu bağlamda, matematik eğitimi başta olmak üzere birçok ülkenin eğitime bakış açısı köklü değişikliklere uğraşmış ve eğitimden beklenen çıktıları farklılaştırmıştır. Eğitim sistemindeki bu gelişmelerle birlikte öğrenme girdilerinin yeniden değerlendirilmesi, öğretim politikasını merkeze alan bir anlayışın gelişmesi ile öğrenme ortamlarının yeniden organize edilmesi zorunlu bir hal almıştır. Bu doğrultuda ortaya çıkan öğrenme modellerinden birisi de geleneksel eğitimin tersine işlediği, harmanlanmış (blended) bir öğrenme süreci olan ters yüz öğrenme (flipped learning) modelidir (Bolat, 2016; Görü-Doğan, 2015).

Son on yıllık süreçte popülerliği artan ters yüz sınıf modeli, günümüzde eğitimin birçok alanında sıklıkla kullanılmaktadır. Başta eğitim ve mühendislik alanları olmak üzere birçok öğretim kademesinde tercih edilmektedir (Bolat, 2016; Muir, 2017). Alanyazında matematik eğitimi alanında sınırlı sayıda çalışmalar bulunsa da matematik öğretiminde ters yüz öğrenme modelinin test edildiği çalışmalarda olumlu çıktılar elde edilmiştir (Adams ve Dove, 2018; Güç, 2017; Muir, 2017). Bilindiği üzere, matematik günlük hayatın vazgeçilmezidir. Birçok alanı derinden etkileyen matematik bilimine duyulan gereksinim her geçen gün daha fazla artmaktadır. Matematik olmadan diğer bilimlerin ayakta kalması ve kendini yenileyebilmesi zordur. Bu yüzden dünyayı daha iyi anlamak ve anlamlandırmak için matematiksel bilginin doğasını bilmek oldukça değerli kabul edilmektedir (National Council of Teachers of Mathematics [NCTM], 2000, 2006). Nitekim matematiğin işlevselliğinin farkına varmadan; bilimden, güçten, teknolojiden, üretimden, iletişimden, adaletten, sanattan ve kalkınmadan söz etmek doğru olmaz. Bu durumun en güçlü nedeni ise teknolojinin baş döndürücü süratinde ve sürekliliğinde matematiğin etkisinin kaçınılmaz olmasıdır. Oysa günümüzdeki çok sayıdaki uluslararası sınav sonuçları incelendiğinde, birçok ulus için matematik başarısının istenilen seviyenin oldukça gerisinde olduğu görülmektedir (OECD, 2016; TIMSS, 2016). Bu bulgular ışığında, öğrencilerin matematik öğrenmesini engelleyici birçok faktör grubu sıralanabilir. Ancak nihai amaç, öğrencilerin daha nitelikli matematik öğrenmelerine yelken açabilmektir. Çünkü günümüz eğitim anlayışının önemli felsefeleri arasında öğrenci odaklı yenilikçi bir öğretim anlayışı ile teknoloji birlikteliğini olabildiğince kaynaştırmak yer almaktadır (Milli Eğitim Bakanlığı [MEB], 2018). Bundan dolayı matematik öğretiminde teknolojiden mümkün olduğunca faydalanmak gerekir. Çünkü daha üretken, daha yaratııı ve daha esnek bir matematik öğretimi için teknolojinin etkin kullanımı konusunda daha fazla araştırma ve geliştirme faaliyetlerine intiyaç duyulmaktadır. Bu bakımdan matematik öğretiminde öğrencilerin öğrenmede yaşadığı zorluğu hafifletmek, dersi sevdirmek, derse olan katılımı artırmak ve bilişsel gelişimlerini desteklemek amacıyla kullanabilecek yöntemlerden birisi de ters yüz öğrenme modelidir. Bu modelin en güçlü yönü yirmi birinci yüzyıl dijital çağın becerilerini öğrenenlere kazandırmak için öğrenme ortamlarını mevcut kimliğinden uzaklaştırarak farkı öğrenme ortamların oluşmasına ve öğrenme ihtiyaçların daha kolay giderilmesine olanak sağlamasıdır.

\subsection{Kuramsal Çerçeve}

Teknolojik araç ve gereçlerin kullanım alanlarının hızlı yayılışı ile birlikte son on yıllık süreçte ters yüz öğrenme modelinin yıldızı giderek parlamış ve birçok alanda sıklıkla tercih edilir hale gelmiştir (Bergmann ve Sams, 2012; Lo, Lie ve Hew, 2018; Sams ve Bergmann, 2013). Teknolojik aletlerin düzenli ve sistematik bir biçimde öğrenme/öğretme faaliyetlerinde kullanılması ters yüz öğretim 
modeli olarak tanımlanmaktadır (Strayer, 2012). Kısacası ters yüz öğrenme modeli; yeni bir öğrenme modelinden öte kalıpları değiştirme sanatı olarak nitelendirilebilir. Geleneksel öğretim yönteminde öğrenciler konuyu okulda öğrendikten sonra genellikle ev ödevleri ile konuları pekiştirmektedir. Ters yüz öğrenme anlayışında öğrenciler teknolojik imkânlar (film, video, metin, ses kaydı vb.) yardımıyla ders içeriğini istediği zaman ve mekânda öğrenip konunun pekiştirilmesini sınıf ortamına taşımaktadır. Başka bir ifade ile geleneksel eğitim sürecinin tersine işleyen bir öğrenme modelidir (Fulton, 2012; Görü-Doğan, 2015; Talbert, 2012). Bu sistem sınıf ortamında öğrencilerin derste aktif yer almaları için zaman kısıtııı̆ını ortadan kaldırarak ek zaman yaratır (Bergmann ve Sams, 2012). Öğrenciler öğrenmeleri/edinmeleri gereken yeterli düzeydeki bilgi/kazanımları teknoloji yardımıyla sınıf ortamı dışında edinirken, ders öğretmenleri ve arkadaşları ile üst düzey düşünme becerilerini kullanır (Bergmann ve Sams, 2012; Fulton, 2012; Strayer, 2012). Bu model sayesinde zaman ve mekân bağımlılı̆ı ortadan kalkar, sınıf içi uygulama desteği artar, öğrencinin merkezde olduğu bir eğitim felsefesine kapı aralanmış olunur (Grover ve Stovval, 2013; LaFee, 2013).

Ters yüz öğrenme modelinin belki de en değerli özelliği farklı türden eğitim kurumlarında veya kademelerinde uygulanabilen bir sistem olmasıdır. Bu bakımdan farklı coğrafyalarda yaşayan farkı sosyo-ekonomik düzeye sahip, farklı kademedeki öğrencilere uygulanarak onları başarıya taşıyabilir (Johnson ve Renner, 2012). Çünkü ters yüz öğrenme modelinde erişime açık eğitsel içerikli kaynaklar veya ders materyalleri öğretmenlerce dijital olarak ortak bir platform üzerinden öğrenenlerle paylaşılır. Öğrenenler okula gelmeden yüklenen dosyaları inceler ve derse ön hazırlık yapmış olurlar. Öğretmen öğrencilerden gelen istek/öneri ve geri dönütleri derse gelmeden önce inceler ve gerekli tedbirleri alır. Böylelikle anlaşılmayan ya da belirsizliğe neden olan kısımlar net bir şekilde belirlenerek açıklanır. Öğrenciler sınıf dışında videoları, ders sunumları, öğretim yöntem sistemleri gibi çoklu ortam araçlarını kullanırken sınıf ortamında öğrendiklerini pekiştirme imkânı bulur (Çakır, 2017; Fulton, 2012). Nitekim LaFee'ye (2013) göre, ters yüz öğrenme modeli öğrencilerin sınıf dışı çalışma sürelerini etkili bir şekilde ayarlamalarına olanak tanır. Bu sayede öğretmenler, öğrencilerin hazırbulunuşluk düzeylerinden yararlandığı sınıf atmosferinde daha fazla zamana sahip olurlar. Bu model, ders öncesinde teorik konuların evde öğrenci tarafından öğrenilmesini ve ders içinde bol miktarda uygulama yaparak daha kalıcı öğrenmeleri gerçekleştirmeyi hedefler (Karaca ve Ocak, 2017).

Tüm bu anlatımların yanı sıra ters yüz öğrenme modeli birtakım dezavantajlara da sahiptir. Örneğin iyi bir internet bağlantısı olması gerekir. Ayrıca devam etme zorunluluğu olmadığı için ilgi zamanla düşebilir. Okul ve sınıf kavramlarının zamanla zedelenmesine neden olabilir. Öğrencilerin öğrenme hızları dikkate alınmadığı için bu sorun oluşturabilir. Yanlış öğrenmeye veya kavram yanılgısına neden olabilir (Johnson ve Renner, 2012; Miller, 2012; Moravec ve diğer., 2010; Sams ve Bergmann, 2013; Strayer, 2012). Öğrencilere göre, ters yüz öğrenme modelinin dezavantajları ise anında geri-dönüt almamak, teknik araç eksikliği, videoların önceden izlenme zorunluluğu ve fazla zaman gerektirmesi şeklinde sıralanmıştır (Turan ve Göktaş, 2015). Sonuç olarak, ters yüz öğrenme modeli öğrencilerin derste görecekleri konularından bireysel öğrenmeye uygun kısımlarını evde eş zamansız sistemler yardımıyla öğrenmesi ve anlaşılmayan kısımların sınıf ortamında giderilmesi ilkesine dayanır. Bir başka ifade ile sınıf içi ders işleyişi ile ödevlerin yer değiştirilmesidir (Bolat, 2016; Fulton, 2012; Bergmann ve Sams, 2012). Bu model, ders materyallerinin hazırlanması ve sunulması gibi durumlarda öğretmenin iş yükünü artırır ancak öğrencilerin öğrenme sürecinde daha aktif rol oynamaları, kendi bireysel öğrenme sorumluluklarını almaları ve sıkıcı bulduğu ev ödevleri sürecinin dönüştürülmesiyle sınıf içi aktivitelere daha fazla zaman ayırmalarına olanak sağlar (Gençer, 2015; Sams ve Bergmann, 2013).

Alanyazın incelendiğinde, Love, Hodge, Grandgenett ve Swift (2014) tarafından lineer cebir dersinde 55 lisans öğrencisi ile yürütülen çalışmada, ters yüz öğrenme modeli uygulanan öğrencilerin akademik başarıları ile sınıf içi performanslarının geleneksel yöntem ile öğrenim gören öğrencilere göre, daha iyi olduğu belirtilmiştir. Ayrıca ters yüz öğrenme modeline karşı öğrencilerin 
olumlu tutum ve görüşlere sahip olduğu sonucuna ulaşılmıştır. Güç (2017) tarafından "rasyonel sayılar/rasyonel sayılarla işlemler" konusunda ters yüz sınıf modelinin öğrencilerin matematik dersi başarılarına ve derse yönelik tutumlarına etkisi araştırılmıştır. Yarı deneysel olarak yürütülen çalışma sonucunda, deney grubunun matematik başarısı kontrol grubuna göre, anlamlı derece yüksek bulunmuştur. Öğrencilerin tutum puanları arasında ise anlamlı bir fark bulunmamıştır. Strayer (2012) tarafından istatistik dersinde uygulanan ters yüz öğrenme modelinde, modelin uygulandığı öğrenci grubunun yeniliğe ve işbirliğine geleneksel öğrenim gören öğrencilerden daha açık olduğu fakat öğrenme görevine yönelme açısından daha düşük memnuniyete sahip oldukları rapor edilmiştir. Yavuz (2016) tarafından 27 öğrenci ile yürütülen bir diğer çalışma sonucunda, deney ve kontrol grubundaki öğrencilerin akademik başarı puanlarının farklılaşmadığı belirlenmiştir. Ancak öğrenciler; uygulanan modeli beğendiklerini, diğer derslerde de kullanılmasının yararlı olabileciğini ve motivasyonlarını artırdığını dile getirmişlerdir. Özdemir (2016) tarafından 49 öğrenci ile harmanlanmış öğrenme ortamında ters yüz sınıf modelinin matematik dersindeki akademik başarıya, kaygıya ve teknolojik tutuma etkisi incelenmiştir. Çalışma sonucunda, ters yüz sınıf modeli uygulamasının öğrencileri olumlu yönde motive ettiği, akademik başarıları ile teknolojik tutumlarını arttırdığı, matematik kaygılarını düşürdüğg̈ belirlenmiştir. Zappe ve diğer., (2009) tarafından gerçekleştirilen bir diğer çalışmada ise ters yüz öğrenme modeline yönelik öğrencilerin kullanım ve algıları araştırımıştır. Çalışma sonunda, öğrencilerin büyük bölümü ders öncesinde videoları izlemeye istekli olduğunu ve ters yüz öğrenme modelinin kavramları anlamalarına yardımcı olduğunu belirtilmiştir. Benzer şekilde, Çakır (2017) tarafından 53 (26 deney, 27 kontrol) öğrenci ile yürütülen çalışma sonucunda, fen bilimleri akademik başarısının deney grubu lehine anlamlı olduğu belirlenmiştir. Diğer yandan öğrencilerin zihinsel risk alma becerileri arasında anlamlı bir fark olmadığı rapor edilmiştir. Aydın (2016) tarafından 44 öğrenci ile yürütülen yarı deneysel çalışma sonucunda ise deney grubunun kontrol grubuna göre, akademik başarı testi puanı yüksek iken ödev/görev stres testi puanı düşük bulunmuştur. Adams ve Dove (2018) tarafından yürütülen çalışmanın bulguları, ters yüz öğrenme modelinin öğrencilerin matematik başarısına pozitif yönde artış sağlamada önemli bir potansiyele sahip olduğu belirtilmiştir. Turan (2015) tarafından 116 (58 deney, 58 kontrol) öğrenci ile yürütülen çalışmada, ters yüz sınıf yöntemi ile öğrenim gören öğrencilerin geleneksel yöntemle öğrenim gören öğrencilere göre başarı ve motivasyon düzeylerinin daha yüksek olduğu fakat bilişsel yüklemelerinin daha düşük olduğu tespit edilmiştir. Ayçiçek ve Yelken (2017) tarafından ingilizce öğretiminde ters yüz öğrenme modelinin derse katılıma etkisi ön-test/son-test yarı deneysel olarak incelenmiştir. Çalışma sonucunda, deney grubuyla işlenen ters yüz öğrenme modelinin ön-test ile son-test puanlarından duyuşsal katılım, uyma/itaat, sınıf katılımı, bilişsel katılım ve derse katılmama puanları arasında anlamlı fark bulunmuştur. Diğer yandan mevcut öğrenme metoduyla ders işleyen kontrol grubunun derse katıım alt boyutlarının tamamında anlamlı bir fark bulunmamıştır.

Alanyazında yer alan çalışmalar dikkate alındığında, ters yüz öğrenme yaklaşımının yaygın olarak kullanıldı̆̆ı ve öğrenci başarısı üzerinde olumlu etkileri olduğu görülmektedir. Ancak bazı ülkelerde tam tersi bir durum yaşanmaktadır (Bolat, 2016; Karaca ve Ocak, 2017). Oysa web tabanlı etkileşimli öğrenme platformlarının, çevrimiçi video siteleri ile açık erişim kaynaklarının artmasıyla birlikte ters yüz öğrenme modeli güncelliğini koruyarak devam ettirmektedir. Ters yüz öğrenme modeli sayesinde bireyler uygun zaman dilimlerinde bilgiye ulaşma faaliyetlerini rahatlıkla yürütebilir ve derse katılım düzeylerini artırabilir. Dolayısıyla ters yüz öğrenme modelinin bireylerin derse olan katılımına etkisinin incelenmesi araştırmaya değer bir konu olarak karşımıza çıkmaktadır. Yürütülen çalışmanın güçlü yönlerinden birisi de ters yüz öğrenme modelinin öğrencilerin akademik başarısına etkisinden ziyade duyuşsal, davranışsal ve bilişsel katılımların etkisinin belirlemeye çalışıımasıdır. Bu doğrultuda çalışmada ters yüz öğrenme modelinin matematik dersine katılıma etkisi ele alınmıştır. 


\subsection{Araştırmanın Amacı ve Problemleri}

Yürütülen çalışmanın temel amacı, matematik öğretiminde ters yüz öğrenme modelinin öğrencilerin derse katılımına etkisini incelemektir. Araştırma kapsamında aşağıdaki sorulara yanıt aranmıştır:

- Deney ve kontrol grubunun derse katılım envanteri boyutlarının ön-test puanları arasında anlamlı bir fark var mıdır?

- Deney grubunun derse katılım envanteri boyutlarının ön-test ile son-test puanları arasında anlamlı bir fark var mıdır?

- Kontrol grubunun derse katılım envanteri boyutlarının ön-test ile son-test puanları arasında anlamlı bir fark var mıdır?

- Deney ve kontrol grubunun derse katılım envanteri boyutlarının ön-test ile son-test puanları arasında anlamlı bir fark var mıdır?

\section{YÖNTEM}

\subsection{Araştırmanın Modeli}

Matematik öğretiminde ters yüz öğrenme modelinin öğrencilerin derse katılımına etkisinin incelendiği çalışmada, nicel araştırma yöntemlerinden yarı deneysel desen kullanılmıştır. Yarı deneysel desenin deneysel desenden farkı deney ve kontrol gruplarının seçkisiz olarak belirlenmemiş olmasıdır (Karasar, 2013). Öncelikle çalışma için öğrencilere ön bilgilendirme çalışması yapılmış, çalışmada gönüllü olarak yer almak isteyen öğrencilerden bir uygulama havuzu oluşturulmuştur. Çalışmaya katılmak isteyen sekizinci sınıf düzeyinde toplam 36 öğrenci ön talepte bulunmuştur. Çalışmada yer almak isteyen bu öğrencilere süreç hakkında ayrıntılı bilgilendirme yapılmıştır. Ön uygulama sonucunda uzaktan eğitim için gerekli fiziki alt yapıya sahip 18 öğrenci deney, kalan 18 öğrenci ise kontrol grubuna dâhil edilmiştir. Yapılan ön-test sonuçlarına göre, aralarında anlamlı farklıık bulunmayan bu iki farklı grup deney ve kontrol grubu olarak ayrılmıştır. Kontrol grubundaki öğrenciler ile geleneksel öğretim yapılmıştır. Öğrencilere konu öğretmen tarafından düz anlatım yoluyla ile işlenmiştir. Öğretmen öğrencilere işlemiş olduğu konularla ilgili notlar tutturmuş, ders sırasında sorular yöneltmiştir. Çalışma kitabında yer alan etkinlikler yaptırımış ve sorular çözdürülmüştür. Ders sonunda öğretmen konuyu özetleyerek dersi bitirmiştir. Deney grubundaki öğrenciler ile ters yüz öğrenmeye göre öğretim yapılmış; öğrenme yönetim sistemine yüklenen etkileşimli konu videoları ve çevrimiçi olarak paylaşılan ders materyalleri ile öğrencilerin derse gelmeden konuyu öğrenmelerine yardımcı olunmaya çalışılmıştır. Dersin başında varsa anlaşılmayan konular/noktalar tekrar edilmiş ve bol miktarda uygulamalı etkinlik yapılmıştır. Deney grubu için etkileşimli videoların kullanıldığı video öğrenme yönetim sistemi ve sistem üzerinden elde edilen veriler "deneysel grupta gerçekleştirilen uygulamalar" başılıkı bölümde ayrıntılı bir şekilde açıklanmıştır. Her iki grupta uygulanan öğretim yöntemleri haftalara göre değişiklik göstermekle birlikte soru-cevap, gösterip yaptırma, problem çözme, tartışma yöntemleri kullanılmıştır. Kontrol grubunda ev ödevi olarak verilen çalışma kâğıtlarından oluşan etkinlikler deney grubunda sınıf içerisinde yapılmıştır. Deney ve kontrol grubunda uygulanan yöntemlerin en önemli farkı ters yüz öğrenmenin uygulandığı deney grubunda ders öncesinde öğrencilerin etkileşimli ders videoları aracılı̆̆ıyla ders konusunun teorik kısımlarını öğrenmeleri ve ders içerisinde bol miktarda uygulamalı etkinlik çalışması yapmalarıdır. Ters yüz öğrenmenin uygulandığı deney grubunda, uzaktan ve yüz yüze eğitimin avantajlı yönleri biraya getirilmeye çalışılmıştır. Yürütülen eğitim faaliyeti sonucunda her iki gruba da derse katıım ölçeği son-test uygulanarak sonuçlar analiz edilmiştir.

\section{2 Çalışma Grubu}

Araştırmanın çalışma grubunu, 2017-2018 öğretim yılında, İzmir şehir merkezindeki bir devlet ortaokulunda öğrenim gören toplam 36 sekizinci sınıf öğrencisi oluşturmaktadır. Öğrencilerden 
\%53'ü ( $N=19)$ kız, \%47'si ( $N=17)$ erkektir. Öğrencilerin uygulama konusunu ilk defa görüyor olması ve yapılan ön-test uygulama puanları arasında farklılık olmaması nedeniyle belirlenen gruplar birbirine denk kabul edilmiştir. Aşağıdaki tabloda cinsiyete göre, deney ve kontrol grubunda yer alan öğrenci sayıları gösterilmiştir.

Tablo 1. Cinsiyete göre deney ve kontrol grubu sayıları

\begin{tabular}{lccc}
\hline Cinsiyet & Deney Grubu & Kontrol Grubu & Toplam \\
\hline Kız & 10 & 9 & 19 \\
Erkek & 8 & 9 & 17 \\
Toplam & 18 & 18 & 36 \\
\hline
\end{tabular}

\subsection{Veri Toplama Araci}

Araştırmada veri toplama aracı olarak, Wang, Bergin ve Bergin (2014) tarafından geliştirilen ve Sever (2014) tarafından Türk kültürüne uyarlaması yapılan “Derse Katılım Envanteri” kullanılmıştır. Derse katılım envanterinin orijinal çalışması iki düzeyde gerçekleştirilmiştir. Birinci çalışmada envanter 21 madde ve dört faktör altında gruplanmıştır. İkinci çalışmada ise envanterdeki madde sayısı 21'den 24'e çıkmış, faktör sayısı artarak 5'e yükselmiştir. Türk kültürüne uyarlanan ölçek 23 madde ve Duyuşsal Katıım, Davranışsal Katılım (uyma/itaat), Davranışsal Katıım (sınıf katııımı), Bilişsel Katılım ve Derse Katılmama olarak beş boyuttan oluşmaktadır. Duyuşsal Katııım boyutunda 6, Davranışsal Katılım (uyma/itaat) boyutunda 4, Davranışsal Katıım (sınıf katılımı) boyutunda 3, Bilişsel Katılım boyutunda 7 ve Derse Katılmama boyutunda ise 3 madde yer almaktadır. Ölçeğin hesaplanan Cronbach's alpha iç tutarlılık katsayısı sırasıyla $0.87,0.82,0.74,0.89$ ve 0.69 olarak hesaplanmıştır. Diğer yandan ölçeğin üç faktörlü yapısı için yapılan doğrulayıcı faktör analizi (DFA) sonucunda elde edilen uyum indeksleri $x^{2} / \mathrm{sd}=1.92, \mathrm{RMSEA}=0.06, \mathrm{AGFI}=0.81, \mathrm{RMR}=0.06, \mathrm{NNFI}=0.97$, $\mathrm{CFI}=0.97, \mathrm{NFI}=0.95, \mathrm{IFI}=0.97, \mathrm{SRMR}=0.09$ olarak belirlenmiştir. Ölçekte yer alan ifadeler için "her zaman (5), çoğunlukla (4), bazen (3), nadiren (2) ve hiçbir zaman (1)" şeklinde 5'li Likert tipi derecelendirme kullanılmıştır. Ölçme envanterinin boyutlarına ilişkin örnek maddeler aşağıda sunulmuştur.

Tablo 2. Derse katılım envanterinin boyutlarına göre örnek maddeleri

\begin{tabular}{ll}
\hline Boyutlar & Maddeler \\
\hline Duyuşsal Katılım & Kendimi ilgili hissediyorum. \\
${ }^{\text {aD Davranışsal Katıım }}$ & Aklımda kalması gereken şeylere özen gösteriyorum. \\
bDavranışsal Katıım & Sınıftaki tartışmalara etkin olarak katılıyorum. \\
Bilişsel Katılım & Karşılaştığım güçlükleri kendi kendime çözmeye çalışıyorum. \\
Derse Katıımama & Yalnızca çalışıyormuş gibi yapıyorum. \\
\hline
\end{tabular}

aUyma/itaat, b Sınıf Katılımı

\subsection{Verilerin Analizi}

Araştırmadaki veri setinin analizinde; betimsel istatistiksel tekniklerin yanı sıra normallik analizleri, bağımsız örneklemler t-Testi, Mann-Whitney U ve Wilcoxon iş̧aretli Sıralar testi kullanılmıştır. Veri setinden güvenilir sonuçlar elde etmek için grupların birbirinden bağımsız olması, verilerin her birisinin normal dağılım gösterip göstermediği ile grupların varyans eşitliğinin incelenmesi gerekir (Can, 2016). Bunların yanı sıra veri setinin çarpıklık katsayıları da incelenerek daha sağıklı kararlar alınabilir (George ve Mallery, 2003). Öncelikle veri setinin normal dağılım gösterip göstermediği incelenmiş, grup büyüklüğü 50'den küçük olduğu için Shapiro-Wilk normallik testi dikkate alınmıştır. Verilerin analizinde SPSS 22.0 paket programı kullanılmıştır.

\subsection{Deneysel Grupta Gerçekleştirilen Uygulamalar}

Yürütülen çalışmada uygulama sürecinin devam ettiği 6 haftalık konuları kapsayan etkileşimli videolar, Eğitim Bilişim Ağı (EBA) üzerinden yayın yapan bir eğitim ve öğretim platformu olan 
"Okulistik" ders yazılımları aracılığıyla elde edilmiştir. Gerekli yasal izinler alındıktan sonra etkileşimli konu anlatımlarına, etkinliklere, problemlere ve konu testlerine öğretmen erişimi modülü üzerinden ulaşılmıştır (URL-1). Sonrasında ters yüz öğrenme için geliştirilmiş olan "Edpuzzle" çalışma platformu üzerinden videolara ipucu, çoktan seçmeli sorular, dış link yönlendirme gibi birtakım etkileşim özellikleri kazandırılmıştır (URL-2). Çalışmada Edpuzzle öğrenme platformunun tercih edilmesinin birtakım avantajları bulunmaktadır. Edpuzzle ters yüz öğrenme modeli uygulamalarında kullanılabilecek etkili sanal sınıf uygulamalarından birisidir. Aynı zamanda Edpuzzle uygulaması ile videolar düzenlenebilir, kendi sesimizle anlatım yapılabilir, sesli notlar eklenebilir, videolara eklenen sorulara öğrencilerin verdikleri cevaplar gözden geçirilebilir, oluşturulan videoyu öğrencinin izleyip izlemediği kontrol edilebilir. Dolayısıyla Edpuzzle kullanışlı ve ücretsiz bir sanal sınıf uygulamasıdır (URL-2). Bu bağlamda öğrencilere bir sınıf kodu verilerek öğrenme platformunda oluşturan sanal sınıfa girmeleri sağlanmıştır. Etkileşimli videoların içerikleri "Geometrik Cisimler" öğrenme alanını kapsayan kazanımlardan oluşmaktadır (MEB, 2018). ilgili konu seçimi öğretim programının (yıllık plan) işleyeşine uygun olarak yapılmıştır. Ders videolarını içeren kazanımların kapsamı haftalık olarak Tablo 3'de gösterilmiştir.

Tablo 3. Etkileşimli videoları içeren kazanımlar

\begin{tabular}{|c|c|c|}
\hline \multicolumn{2}{|r|}{ HaftaHaftalık Olarak Etkileşimli Videoları İçeren Kazanımlar } & \multirow{2}{*}{$\begin{array}{l}\text { Materyaller } \\
\text { Konu Videosu, }\end{array}$} \\
\hline 1 & Dik prizmaları tanır, temel elemanlarını belirler, inşa eder ve açınımını çizer & \\
\hline 2 & $\begin{array}{l}\text { Dik dairesel silindirin temel elemanlarını belirler, inşa eder ve açınımını } \\
\text { çizer. }\end{array}$ & $\begin{array}{l}\text { Videolu Soru } \\
\text { Çözümü, }\end{array}$ \\
\hline 3 & $\begin{array}{l}\text { Dik dairesel silindirin yüzey alanı bağıntısını oluşturur, ilgili problemleri } \\
\text { çözer }\end{array}$ & $\begin{array}{l}\text { Konu Testi, } \\
\text { Zenginleştirilmiş }\end{array}$ \\
\hline 4 & Dik dairesel silindirin hacim bağıntısını oluşturur; ilgili problemleri çözer. & E- Kitap \\
\hline & Dik piramidi tanır, temel elemanlarını belirler, inşa eder ve açınımını çizer. & \\
\hline & Dik koniyi tanır, temel elemanlarını belirler, inşa eder ve açınımını çizer & \\
\hline
\end{tabular}

Kazanımlara uygun olarak Okulistik öğrenme platformundan ulaşılan bazı ders videolarının ekran görüntüleri aşağıda gösterilmiştir.

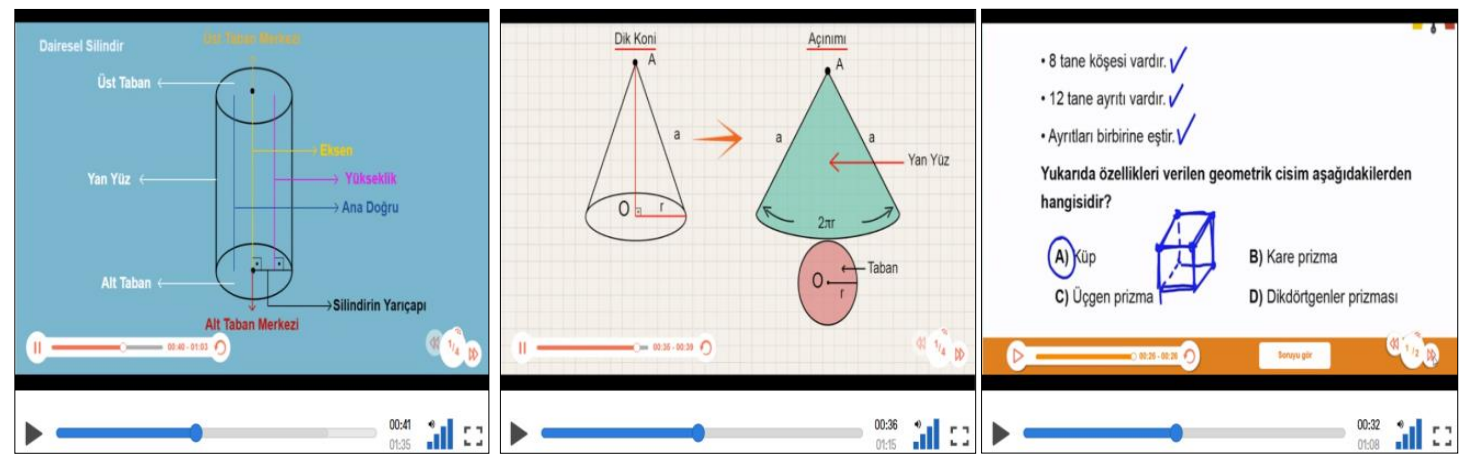

Şekil 1. Okulistik Kazanıma Uygun Ders Videoları

Edpuzzle platformuna yüklenerek etkileşimli hale getirilmiş ve kazanıma uygun olarak hazırlanmış ders videolarına ait sistem görüntüsü ise Şekil 2'de gösterilmiştir. 


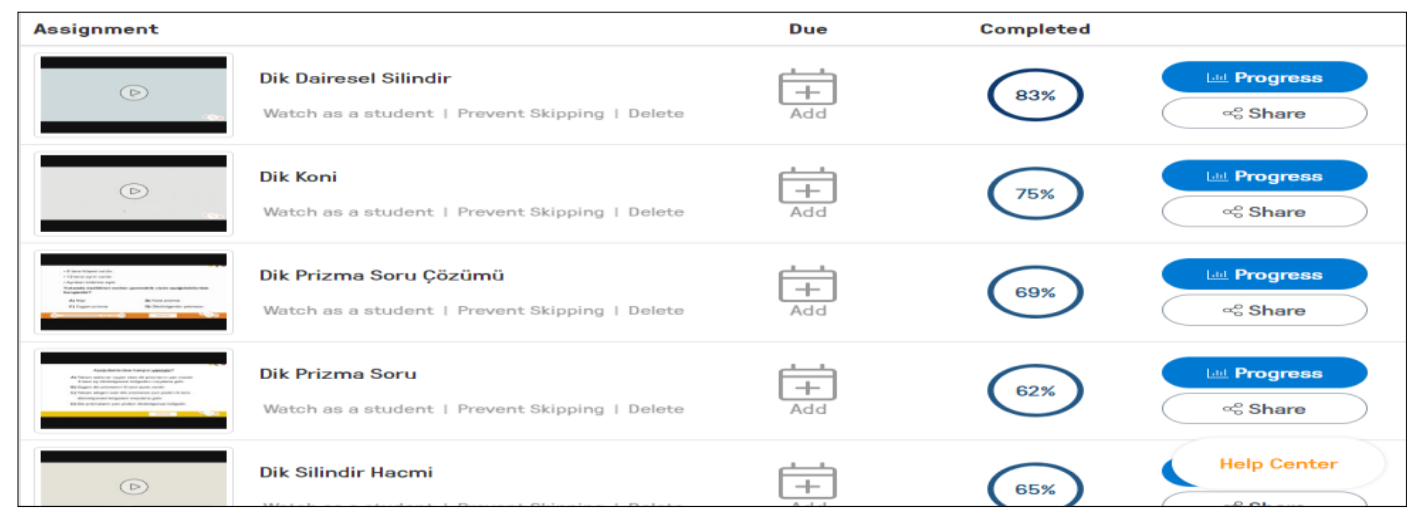

Şekil 2. Edpuzzle Platformunda Öğrencilerle Paylaşılan Etkileşimli Videolar

Diğer yandan öğretmen sınıfındaki öğrenciler tarafından izlenen videoların izlenme süresini ve oranlarını görebilmektedir. Ayrıca öğrenciler izlediği video üzerindeki sorulara verdiği cevapların sonuçlarını anında görebilmektedir. Öğrencilerin seçilen bir ders videosunu izleyip izlemediklerini gösteren ekran görüntüsü Şekil 3'de gösterilmiştir.

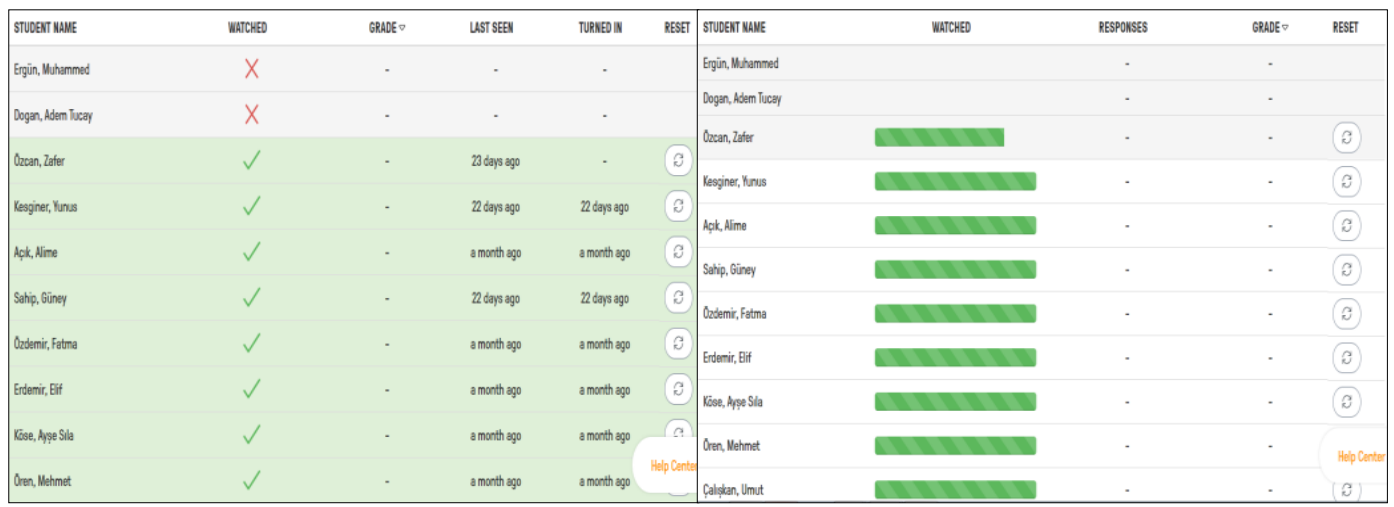

Şekil 3. Edpuzzle Platformunda Öğrencilerle Paylaşılan Etkileşimli Videolara Ait Veriler

Ters yüz öğrenme yönetim sitemi sayesinde derse yönelik hazırlanan etkileşimli videolar üzerinden öğrencilerin dersleri takip etme yüzdeleri izlenebilmektedir. Bunun yanı sıra kazanımlara uygun sorular yöneltilebilmekte ayrıca geri dönütler alınabilmektedir. Bu sayede öğrencilerin öğrenmekte zorlandıkları kısımlar/bölümler belirlenebilmekte ve bu eksiklikler giderilebilmektedir. Diğer yandan ters yüz öğrenmenin en büyük dezavantajı olarak görülen öğrencilerin videoları izlememesi ya da izledikleri halde konuyu öğrenmemiş olarak sınıfa gelmesi durumlarına çözüm üretilebilmektedir. Dolayısıyla öğrencilerin ders öncesi hazır bulunuşlukları etkileşimli videolar sayesinde desteklenmekte ve izlenen bu videolar ders sonu değerlendirme için bir ölçüt olarak alınarak videoların takip edilmesi teşvik edilmektedir.

\subsection{Uygulama}

Öncelikle uygulama öğrencileri arasında yer almayan sekiz öğrenci ile geometrik cisimler öğrenme alanı içerisinde yer alan dik prizmalar konusuna yönelik iki ders saati süresince pilot çalışma yürütülmüştür. Çalışmadan önce öğrenciler uygulama konusunda bilgilendirilmiş ve gönüllülük esas alınmıştır. Sonrasında öğrencilere dersten önce öğrenme yönetim sistemi üzerinden ders videoları gönderilmiş, anlamakta zorlandıkları veya güçlük çektikleri kısımlar açıklanmıştır. Bu sayede uygulama sırasında aksaklığa neden olabilecek olumsuzluklar belirlenmeye çalışıımıştır. Belirlenen olumsuzlukların başında ise genellikle internete erişim sorunu gelmektedir. Uygulamanın yapıldığı çalışma 6 hafta boyunca sekizinci sınıf düzeyinde 36 öğrenci ile yürütülmüştür. Yapılan ön-test sonuçlarına göre aralarında anlamlı bir farklıık bulunmayan gönüllü öğrenciler iki grubu ayrılmış ve sınıflardan birisi kontrol diğeri deney grubu olarak atanmıştır. 
Deney ve kontrol grubu öğrencilerine matematik öğretim programına göre, sunumlar yapılmıştır. Deney grubunda haftalık olarak temin edilen videolar dersten önce öğrenme yönetim sistemi üzerinden yüklenilerek videoyu izlemeleri sağlanmıştır. Bu sayede öğrencilerin dersin ana hatlarını (kazanıma uygun) video üzerinden öğrenmeleri sağlanmış, varsa anlamadıkları kısımlar açıklanmıştır. Bunun yanı sıra ders videolarını içeren etkinlikler yapılmış, öğrencilerin eksik anlamaları giderilmeye çalışılmıştır. Daha sonra her hafta için planlanan ders kazanımları, etkinlikler, e-kitap alıştırmaları ders içi etkileşim esas alınarak işlenmiştir. Geleneksel öğretim planı uygulanan kontrol grubunda ise sadece yüz yüze eğitim yapılmıştır. Kontrol grubuyla yürütülen derslerde konu anlatımı yapılmış, örnekler çözülmüş ve ev ödevleri verilmiştir. Ayrıca hem deney hem de kontrol grubu öğrencileri ile sürekli iletişim halinde olunarak, rehberlik edilmiştir.

\section{BULGULAR}

$\mathrm{Bu}$ bölümde araştırmanın amacına uygun olarak, uygulamaya başlamadan önce öğrencilere yöneltilen derse katıım envanterine ait ön-test sonuçlarının deney ve kontrol grupları arasında anlamlı bir farklılık olup olmadığı belirlenmeye çalışılmıştır. Bu bağlamda deney ve kontrol gruplarının ölçme envanterinin boyutlarından elde ettikleri puanlara ait ortalama, standart sapma, ortanca, varyans, dağılım aralığı, çarpıklık ve basıklık katsayıları aşağıda verilmiştir.

Tablo 4. Deney ve kontrol grubunun elde ettikleri ön-teste ait betimsel değerler

\begin{tabular}{llccccc}
\hline Gruplar & Betimsel Değerler & B1 & B2 & B3 & B4 & B5 \\
\hline \multirow{6}{*}{ Deney } & Ortalama & 18.96 & 16.64 & 10.20 & 23.03 & 6.27 \\
& Standart Sapma & 0.56 & 0.58 & 0.99 & 0.73 & 0.68 \\
& Ort./Madde Sayısı & 3.02 & 4.16 & 3.40 & 3.29 & 2.09 \\
& Ortanca & 3.16 & 4.25 & 3.33 & 3.35 & 2.00 \\
& Varyans & 0.31 & 0.33 & 0.98 & 0.54 & 0.48 \\
& Dağılım Aralığı & 1.83 & 2.00 & 4.00 & 3.00 & 2.00 \\
& Çarpıklık & -0.58 & -0.14 & -0.21 & -1.60 & -0.03 \\
& Basıklık & -0.82 & -0.70 & 0.91 & 1.32 & -1.41 \\
\hline \multirow{4}{*}{ Kontrol } & Ortalama & 18.60 & 16.60 & 11.43 & 25.48 & 7.26 \\
Grobu & Standart Sapma & 0.52 & 0.70 & 0.68 & 0.75 & 0.86 \\
& Ort./Madde Sayısı & 3.10 & 4.15 & 3.81 & 3.64 & 2.42 \\
& Ortanca & 3.16 & 4.12 & 3.83 & 3.85 & 2.50 \\
& Varyans & 0.27 & 0.49 & 0.47 & 0.56 & 0.75 \\
& Dağılım Aralığı & 1.67 & 2.25 & 2.33 & 2.71 & 3.00 \\
& Çarpıklık & -0.31 & -0.49 & -0.04 & -0.19 & -0.09 \\
& Basıkık & -0.77 & -0.60 & -0.95 & -0.60 & -1.03 \\
& Toplam Öğrenci Sayısı & 36 & 36 & 36 & 36 & 36 \\
\hline
\end{tabular}

B: Boyut; B1: Duyuşsal Katıım; B2: Davranışsal Katııı (uyma/itaat); B3: Davranışsal Katııı (sınıf katııımı); B4: Bilişsel Katılım; B5: Derse Katılmama

Tablo 4'e göre, deney ve kontrol grubunun derse katılım envanterinin her bir boyutundan elde etkileri ön-test puanlarının çarpıklık ve basıkık değerlerinin \pm 2 aralığında olduğundan değişkenlerin normal dağılıma sahip olduğu görülmektedir (George ve Mallery, 2003). Deney ve kontrol gruplarındaki en yüksek ön-test ortalama puanı davranışsal katılım (uyma/itaat) boyutunda iken en düşük ortalama puanı derse katılmama boyutunda olmuştur. Derse katılım envanterinin her bir boyutuna ait puanları içeren normallik sonuçları aşağıda verilmiştir. 
Tablo 5. Deney ve kontrol grubunun ön-test normallik analizi

\begin{tabular}{llcccccc}
\hline & \multicolumn{6}{c}{ Kolmogorov-Smirnov } & \multicolumn{3}{c}{ Shapiro-Wilk } \\
Boyutlar & Gruplar & İstatistik & $\mathrm{df}$ & $\mathrm{p}$ & istatistik & $\mathrm{df}$ & $\mathrm{p}$ \\
\hline B1 & Deney & 0.21 & 18 & 0.49 & 0.91 & 18 & 0.09 \\
& Kontrol & 0.13 & 18 & 0.20 & 0.94 & 18 & 0.32 \\
B2 & Deney & 0.15 & 18 & 0.20 & 0.94 & 18 & 0.39 \\
& Kontrol & 0.13 & 18 & 0.20 & 0.92 & 18 & 0.17 \\
B3 & Deney & 0.19 & 18 & 0.06 & 0.91 & 18 & 0.09 \\
& Kontrol & 0.20 & 18 & 0.05 & 0.92 & 18 & 0.18 \\
B4 & Deney & 0.21 & 18 & 0.02 & 0.85 & 18 & 0.51 \\
& Kontrol & 0.16 & 18 & 0.19 & 0.96 & 18 & 0.65 \\
B5 & Deney & 0.14 & 18 & 0.20 & 0.90 & 18 & 0.07 \\
& Kontrol & 0.14 & 18 & 0.20 & 0.94 & 18 & 0.32 \\
\hline P0.05
\end{tabular}

$\mathrm{p}<0.05$

Tablo 5 incelendiğinde, örneklem sayısının uygun olduğu Shapiro-Wilk testinin anlamlılık değeri derse katılım envanterinin tüm boyutlarında anlamlılık değerinden büyük olduğu için \%95 güvenle veriler normal dağılım göstermektedir. Bunun yanı sıra bağımsız örneklemler t-testi için bir diğer şart olan varyansların eşitliği ile varyans eşitliğinin sağlanması koşuluyla gerçekleştirilen bağımsız örneklemler t-testi sonuçları aşağıdaki tabloda verilmiştir.

Tablo 6. Deney ve kontrol grubunun varyans eşitliği ile t-testi ön-test sonuçları

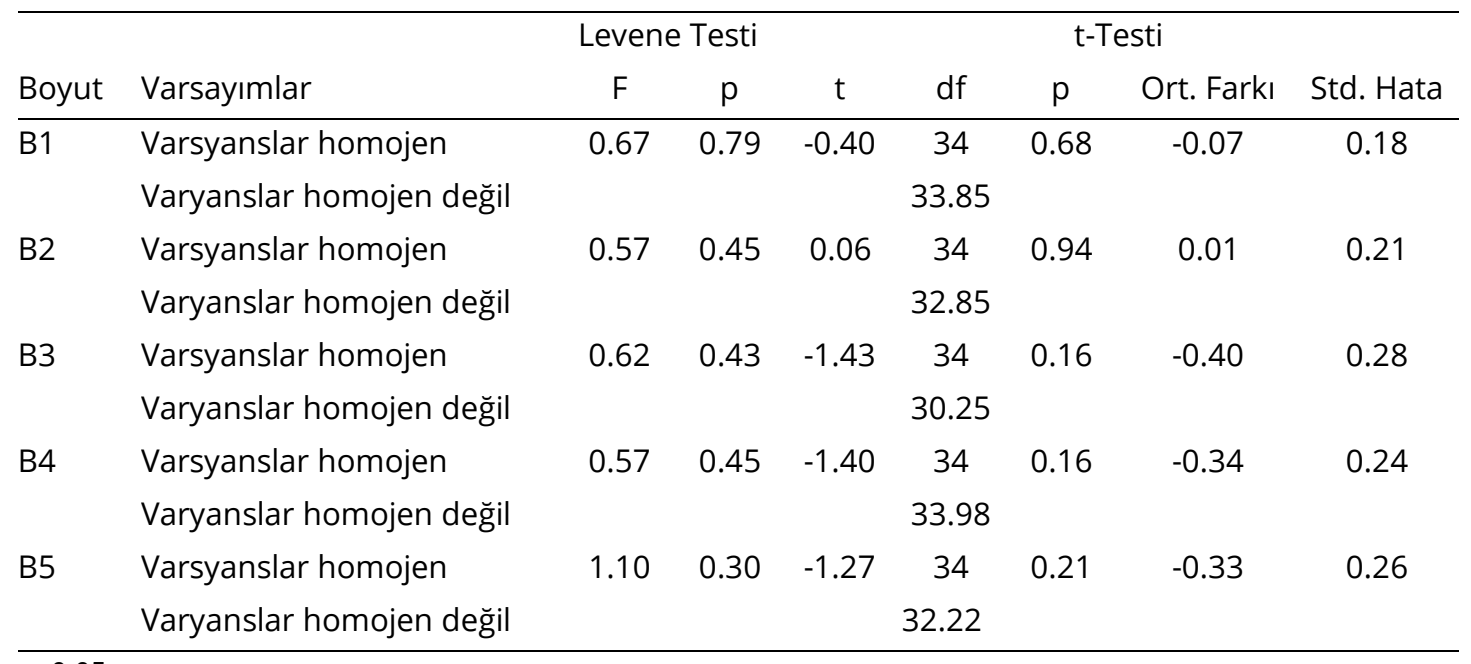

$\mathrm{p}<0.05$

Tablo 6 incelendiğinde, derse katılım envanterinin duyuşsal, daranışsal (uyma/itaat), davranışsal (sınıf katılımı), bilişsel ve derse katılmama boyutlarına ait elde edilen değerlerin her birinin anlamlılık düzeyinden yüksek çıktığı görülmektedir ( $p>0.05$ ). Bu bağlamda, deney ve kontrol grubunun elde ettikleri değerlerin varyans eşitliğine sahip olduğu söylenebilir. Ön-test sonuçlarına göre, deney ve kontol grubunun derse katılım envanterinden aldıkları puanlar arasında anlamlı bir farkın olup olmadığını belirlemek için varsyas eşitliğinden hareketle bağımsız örneklemler t-testi yapılmıştır. T-testi sonuçları incelendiğinde, deney ve kontrol grubunun ön-test puanları arasında anlamlı bir farklılık bulunmadığı $(p>0.05)$ ve deneysel çalışma için belirli varsayımların karşılandığı görülmektedir. Bu bağlamda 6 haftalık deneysel çalışma için gerekli ön koşulların sağlandığı söylenebilir. Diğer bir adımda, deneysel uygulama sonunda derse katılım envanteri deney ve 
kontrol grubu öğrencilerine tekrar yöneltilerek elde edilen veriler incelenmiştir. Elde edilen bulgular aşağıda sunulmuştur.

Tablo 7. Deney ve kontrol grubunun elde etkileri son-teste ait betimsel değerler

\begin{tabular}{llccccc}
\hline Gruplar & Betimsel Değerler & B1 & B2 & B3 & B4 & B5 \\
\hline \multirow{6}{*}{ Deney } & Ortalama & 28.32 & 19.36 & 14.43 & 32.90 & 3.99 \\
& Standart Sapma & 0.35 & 0.24 & 0.26 & 0.35 & 0.44 \\
& Ort./Madde Sayısı & 4.72 & 4.84 & 4.81 & 4.70 & 1.33 \\
& Ortanca & 5.00 & 5.00 & 5.00 & 4.85 & 1.00 \\
& Varyans & 0.12 & 0.06 & 0.06 & 0.12 & 0.19 \\
& Dağılım Aralı̆̆ı & 1.00 & 0.75 & 1.00 & 1.00 & 1.00 \\
& Çarpıklık & -0.85 & -1.34 & -1.85 & -0.80 & 0.67 \\
& Basıklık & -0.77 & 0.54 & 4.58 & -0.70 & -1.51 \\
\hline \multirow{4}{*}{ Kontrol } & Ortalama & 21.90 & 16.44 & 11.43 & 26.11 & 6.66 \\
Grubu & Standart Sapma & 0.74 & 0.93 & 0.74 & 0.66 & 0.77 \\
& Ort./Madde Sayısı & 3.65 & 4.11 & 3.81 & 3.73 & 2.22 \\
& Ortanca & 3.50 & 4.50 & 3.66 & 3.64 & 2.33 \\
& Varyans & 0.55 & 0.87 & 0.55 & 0.43 & 0.60 \\
& Dağılım Aralı̆̆ı & 3.00 & 2.50 & 2.00 & 2.29 & 2.33 \\
& Çarpıklık & 0.01 & -0.70 & 0.47 & 0.41 & -0.14 \\
& Basıklık & 0.46 & -1.12 & -1.16 & -0.80 & -0.97 \\
& Toplam Öğrenci Sayısı & 36 & 36 & 36 & 36 & 36
\end{tabular}

Tablo 7 incelendiğinde, deney ve kontrol grubu öğrencilerinin derse katılım envanterinin her bir boyutundan elde etkileri son-test puanlarının çarpıkık ve basıklık değerlerinden \pm 2 aralığı içinde olmayan değişkenler olduğundan verilerin normal dağılımdan uzaklaştığı söylenebilir (George ve Mallery, 2003). Deney ve kontrol grubundaki en yüksek son-test ortalama puanı davranışsal katılım (uyma/itaat), en düşük ortalama puanı derse katılmama boyutundan elde edilmiştir. Deney ve kontrol grubunun derse katılım envanterinin her bir boyutundan elde ettikleri puanlara ait normallik testleri aşağıda sunulmuştur.

Tablo 8. Deney ve kontrol grubundan elde edilen verilerin son-test normallik analizi

\begin{tabular}{llcccccc}
\hline & \multicolumn{6}{c}{ Kolmogorov-Smirnov } & \multicolumn{3}{c}{ Shapiro-Wilk } \\
Boyut & Gruplar & Statistic & df & Sig. & Statistic & df & Sig. \\
\hline B1 & Deney & 0.33 & 18 & 0.00 & 0.76 & 18 & 0.00 \\
& Kontrol & 0.13 & 18 & 0.20 & 0.95 & 18 & 0.54 \\
B2 & Deney & 0.40 & 18 & 0.00 & 0.67 & 18 & 0.00 \\
& Kontrol & 0.21 & 18 & 0.02 & 0.83 & 18 & 0.00 \\
B3 & Deney & 0.31 & 18 & 0.00 & 0.67 & 18 & 0.00 \\
& Kontrol & 0.19 & 18 & 0.08 & 0.87 & 18 & 0.20 \\
B4 & Deney & 0.29 & 18 & 0.00 & 0.80 & 18 & 0.00 \\
& Kontrol & 0.14 & 18 & 0.20 & 0.94 & 18 & 0.40 \\
B5 & Deney & 0.38 & 18 & 0.00 & 0.68 & 18 & 0.00 \\
& Kontrol & 0.16 & 18 & 0.19 & 0.92 & 18 & 0.12 \\
\hline \hline
\end{tabular}


Tablo 8 incelendiğinde, örneklem sayısının uygun olduğu Shapiro-Wilk testinin anlamlılık değeri derse katılım envanterinin bazı boyutlarında anlamlılık değerinden $(p<0.05)$ küçük olduğu için \%95 güvenle veriler normal dağılım göstermemektedir. Bundan dolayı deney ve kontrol grubunun sontest puanları arasındaki farkın anlamlıık düzeyini belirlemek için Mann-Whitney $U$ testi kullanılmıştır.

Tablo 9. Deney ve kontrol grubundan elde edilen verilere ilişkin Mann-Whitney U testi

\begin{tabular}{llccccc}
\hline Boyut & Gruplar & $\mathrm{N}$ & Sira Ort. & Sira Toplamı & $\mathrm{U}$ & $\mathrm{P}$ \\
\hline B1 & Deney & 18 & 25.53 & 459.50 & 35.50 & $0.00^{*}$ \\
& Kontrol & 18 & 11.47 & 206.50 & & \\
B2 & Deney & 18 & 23.03 & 414.50 & 80.50 & $0.00^{*}$ \\
& Kontrol & 18 & 13.97 & 251.50 & & \\
B3 & Deney & 18 & 24.94 & 449.00 & 46.00 & $0.00^{*}$ \\
& Kontrol & 18 & 12.06 & 217.00 & & \\
B4 & Deney & 18 & 25.44 & 458.00 & 37.00 & $0.00^{*}$ \\
& Kontrol & 18 & 11.56 & 208.00 & & \\
B5 & Deney & 18 & 12.28 & 221.00 & 50.00 & $0.00^{*}$ \\
& Kontrol & 18 & 24.72 & 445.00 & & \\
\hline
\end{tabular}

${ }^{* \mathrm{p}<0.05}$

Tablo 9 incelendiğinde, deney ve kontrol grubu öğrencilerinin derse katılım envanterine ait duyuşsal, davranışsal (uyma/itaat), davranışsal (sınıf katılımı), bilişsel ile derse katılmama boyutlarının son-test puanları arasında anlamlı bir ilişki tespit edilmiştir $(p<0.05)$. Elde edilen bulgura göre, deney grubunun sıra ortalamasının derse katılım envanteri boyutlarının hepsinde kontrol grubundan daha fazla olduğu görülmektedir. Veriler incelendiğinde, deney grubunun sontest puanları kontrol grubuna göre daha yüksektir. Bu bakımdan ters yüz öğrenme modeli uygulanmasının öğrencilerin derse katılım düzeylerini olumlu yönde etkilediği söylenebilir.

Tablo 10. Deney ve kontrol grubunun ön/son test puanları için Wilcoxon İ̧̧aretli Sıralar testi

\begin{tabular}{|c|c|c|c|c|c|c|c|}
\hline Boyut & Grup & Ön/Son Test & $\mathrm{N}$ & Sira Ort. & Sıra Toplamı & $z$ & $p$ \\
\hline & Deney & Negatif Sıralar & - & - & - & -3.73 & $0.00 *$ \\
\hline & & Pozitif Sıralar & 18 & 9.50 & 171.00 & & \\
\hline \multirow[t]{3}{*}{ B1 } & Kontrol & Negatif Sıralar & 2 & 3.25 & 6.50 & -3.18 & $0.00 *$ \\
\hline & & Pozitif Sıralar & 14 & 9.25 & 129.50 & & \\
\hline & Deney & Negatif Sıralar & 2 & 3.50 & 7.00 & -3.02 & $0.00^{*}$ \\
\hline \multirow[t]{4}{*}{ B2 } & & Pozitif Sıralar & 13 & 8.69 & 113.00 & & \\
\hline & Kontrol & Negatif Sıralar & 6 & 7.42 & 44.50 & -0.43 & 0.66 \\
\hline & & Pozitif Sıralar & 6 & 5.58 & 33.50 & & \\
\hline & Deney & Negatif Siralar & 1 & 2.00 & 2.00 & -3.54 & $0.00 *$ \\
\hline \multirow[t]{4}{*}{ B3 } & & Pozitif Sıralar & 16 & 9.44 & 151.00 & & \\
\hline & Kontrol & Negatif Sıralar & 8 & 6.44 & 51.50 & -0.06 & 0.94 \\
\hline & & Pozitif Sıralar & 6 & 8.92 & 53.50 & & \\
\hline & Deney & Negatif Sıralar & - & - & - & -3.62 & $0.00 *$ \\
\hline \multirow[t]{3}{*}{ B4 } & & Pozitif Sıralar & 17 & 9.00 & 153.00 & & \\
\hline & Kontrol & Negatif Sıralar & 5 & 10.85 & 54.00 & -0.72 & 0.46 \\
\hline & & Pozitif Sıralar & 11 & 7.45 & 82.00 & & \\
\hline
\end{tabular}




\begin{tabular}{|c|c|c|c|c|c|c|c|}
\hline & Deney & Negatif Sıralar & 15 & 9.37 & 140.50 & -3.05 & $0.00 *$ \\
\hline \multirow[t]{3}{*}{ B5 } & & Pozitif Sıralar & 2 & 6.25 & 12.50 & & \\
\hline & Kontrol & Negatif Siralar & 7 & 6.36 & 44.50 & -0.43 & 0.66 \\
\hline & & Pozitif Sıralar & 5 & 6.70 & 33.50 & & \\
\hline
\end{tabular}

${ }^{*} \mathrm{p}<0.05$

Tablo 10 incelendiğinde, deney grubunun derse katılım envanterinin ön-test ile son-test puanlarına ait veriler tüm boyutlarda anlamlı bulunmuştur $(p<0.05)$. Kontrol grubunda ise duyuşsal katılımı boyutu dışındaki boyutlarda anlamlı ilişkiye rastlanılmamıştır. Bu sonuçlar ışı̆̆ında, ters yüz öğrenme modelinin matematik öğretimde kullanılmasının derse katılım noktasında pozitif yönde etkilerinin olduğu söylenebilir.

\section{SONUÇ, TARTIŞMA VE ÖNERILER}

Bu çalışmada matematik öğretiminde ters yüz öğrenme modeli kullanılmış ve öğrencilerin matematik dersine yönelik katııımına etkisi incelenmiştir. Alanyazında matematik öğretimi ile ilgili sınırlı sayıda çalışma bulunması araştırmanın en önemli çıkış noktasını oluşturmuştur. Bu bakımdan araştırmadan elde edilen bulguların ilgili literatüre önemli katkılar sağlayacağı umulmaktadır.

Araştırmadan elde edilen betimsel değerlere göre, uygulama öncesi deney ve kontrol grubunun derse katılım düzeyleri birbirine oldukça yakın bulunmuştur. Hem deney hem de kontrol grubunun derse katılım envanterine ait ön-test uygulamasında en yüksek ortalama değer davranışsal katılım (uyma/itaat) boyutu olarak tespit edilmiştir. Bu boyutu sırasıyla davranışsal katılım (sınıf katılımı), bilişsel katılım, duyuşsal katılım ve derse katılmama boyutları izlemiştir. 6 haftalık çalışma sonucunda deney ve kontrol grubunun derse katılım envanterine ait son-test uygulamasında en yüksek ortalama değer davranışsal katılım (uyma/itaat) boyutunda iken en düşük ortalama değer derse katılmama boyutunda olmuştur. Deney ve kontrol grubunun son-test puanları arasında anlamlı bir ilişski olup olmadığını belirlemek için Mann-Whitney $U$ testi uygulanmış ve derse katılım envanterinin tüm boyutları arasında deney grubu lehine istatistiksel olarak anlamlı bir fark bulunmuştur $(p<0.05)$. Özellikle deney grubunun duyuşsal katılım boyutundaki (25.53) ortalama puan farkı kontrol grubundan (11.47) iki kat daha fazla olmuştur. Benzer şekilde, deney grubunun davranışsal katıım (uyma/itaat) (23.03), davranışsal katıım (sınıf katıımı) (24.94), bilişsel katıım (25.44) boyutlarındaki ortalama puan farkı kontrol grubunun davranışsal katılım (uyma/itaat) (13.97), davranışsal katııı (sınıf katılımı) (12.06), bilişsel katııım (11.56) boyutlarının ortalama puan farkından oldukça fazla çıkmıştır. Diğer yandan deney grubunun derse katılmama boyutundaki (12.28) ortalama puan farkı kontrol grubunun derse katılmama boyutundaki (24.72) ortalama puan farkının yarısı kadar olmuştur.

Araştırmadan elde edilen bir diğer bulgu ise deney grubunun ön-test ile son-test derse katılım puanlarının tüm boyutlarında istatistiksel olarak anlamlı çıkmasıdır. Diğer yandan kontrol grubunun ön-test ile son-test derse katılım puanları duyuşsal katılım boyutu dışında anlamlı bir iliş̧ki sergilememiştir. Bu sonuçlar ışı̆̆ında, deney grubuna uygulanan ters yüz öğrenme modelinin öğrencilerin matematik dersindeki katılma düzeylerine olumlu etkileri olduğu söylenebilir. Nitekim bu model sayesinde öğrencilerin duyuşsal, bilişsel ve davranışlsal (itaat /sınıf katılımı) durumları belirgin şekilde etkilenmiştir. Elde edilen bulgular, alanda yürütülen benzer çalışma bulguları ile örtüşmektedir (Çakır, 2017; Fulton, 2012; Güç, 2017; İyitoğlu, 2018; Karaca ve Ocak, 2017; Love ve diğer., 2014; Miller, 2012; Muir, 2017; Özdemir, 2016; Turan, 2015). Bilindiği üzere, öğrencilerin matematik öğrenimine bakış açılarının yanı sıra derslerdeki başarı düzeyleri de alarm vermektedir (OECD, 2016; TIMSS, 2016). Bu yüzden öğrencilerin matematik dersine olan bakış açılarını değiştirmede, derse karşı olumlu tutum oluşturmada, derse daha fazla katılım sağlamada aynı zamanda güvenini üst düzeye taşımada ters yüz öğrenme modeli önemli bir araç olabilir. Nitekim ters yüz öğrenme modeli sayesinde öğrencilerin matematik ders başarısı yükselmekte ve derse 
karşı olumlu tutum geliştirmektedir (Adams ve Dove, 2018; Guerrore ve diğer., 2015; Güç, 2017; Muir, 2017). Özellikle teknoloji desteğini sağlamada, öğretme sorumluluğunu kurumsal yapının dışına taşımada, okul dışı zamanı verimli kullanmada bunların yanı sıra grup çalışması, akran dayanışması ve verimli sosyal etkileşim yardımıyla öğrenme ortamına yeni bir bakış açısı kazandırmada ters yüz öğrenme modeli bilişim çağının kaçınılmaz çıktıları arasında gösterilebilir. Nitekim deney grubunun derse yönelik duyuşsal katılım düzeyinin kontrol grubundan oldukça yüksek çıkması bu durumun en güçlü kanıtı olarak gösterilebilir. Ayçiçek ve Yelken (2017) tarafından ingilizce dersinde denenen ters yüz öğrenme modelinde öğrencilerin ingilizce dersine olan duyuşsal bakış açılarında da uyumlu bulgular elde edilmiştir. Çalışmada deney grubunun davranışsal katıımı içeren uyma/itaat ile yine davranışsal katıımı içeren sınıf katılımı puanlarının yüksek çıkması alanyazında dile getirilen öğrencilerin ters yüz öğrenme modeli sayesinde video izlemede istekli olduğu varsayımını destekler niteliktedir (Zappe ve diğer., 2009). Fulton'a (2012) göre, bu sistem eğitim-öğretim faaliyetine bireysellik kattığı için geleneksel anlayışa göre daha verimlidir. Bunların yanı sıra ters yüz öğrenme modeli ile öğrenim gören deney grubu öğrencilerinin bilişsel katılım düzeyi kontrol grubuna göre daha yüksek çıkmıştır. Bu sonuç, ters yüz öğrenme modeli ile öğrencilerin kavramsal anlamaların geliştiği yönündeki çalısma bulguları ile örtüşmektedir (Zappe ve diğer., 2009). Her ne kadar ters yüz öğrenme modelinin öğrencilerin duyuşsal, davranışsal ve bilişsel olarak derse katılımlarına olumlu etkilerinin olduğu sonucu elde edilse de alanyazında bu durumun başarı puanlarına yansımadığına yönelik çalışma bulgusuna da rastlanılmaktadır (Yavuz, 2016).

Araştırmanın diğer bulgusu, deney grubu öğrencilerinin derse katılmama durumlarının kontrol grubuna göre düşük çıkmasıdır. Araştırmanın bu bulgusuna göre, öğrencilerin dersi bu şekilde işlemekte istekli ve sorumluluk alabilme bilincine sahip oldukları söylenebilir. Nitekim ters yüz öğrenme modeli sayesinde öğrencilerin matematik kaygıları ile görev stresinin azaldığı bilinmektedir (Aydın, 2016; Marlowe, 2012; Özdemir, 2016). Çünkü ödevlerin sınıf ortamına taşınmasıyla birlikte öğrenciler kendilerini rahat hissetmekte, öğrenmede yaşadığı zorlukları ve nasıl bir öğrenme stiline sahip olduğunu rahatlıkla ifade edebilmektedir (Fulton, 2012). Bu duruma dikkat çeken Ayçiçek ve Yelken (2017), ters yüz öğrenme modelinin öğrencilerin derse katılmama isteklerini azalttığını belirtmektedir. Bu yönüyle ters yüz öğrenme modeli dersi eğlenceli ve üretken hale getirmek için birçok avantaja sahiptir. Dolayısıyla öğrencilerin iyi birer matematik okuryazarı olmalarında bu sistem önemli yararlar sağlayabilir. Çünkü matematik okuryazarlığında çalışma disiplini değişkeninin etkisi önemlidir (Aksu ve Güzeller, 2016; MEB, 2011). Bunların dışında özellikle öğrencilerin başarılarını artırmaya yardımcı olması, öğretmen rehberliğini aktif hale getirmesi ve bireysel öğrenmeye yardımcı olması sistemin önemli yararları arasında gösterilebilir. Alanyazında elde edilen benzer bir bulguya göre, ters yüz öğrenme modeli sayesinde öğrenciler, matematik dersine daha etkin katıldıkları yönünde olumlu görüş belirtmişlerdir (Güç, 2017; Muir, 2017).

Elde edilen bulgular genel olarak değerlendirildiğinde, ters yüz öğrenme modelinin matematik dersine daha aktif katılımı desteklediği söylenebilir. Harmanlanmış öğrenme yöntemlerinden biri olarak görülen model, öğrencilerin matematik derslerine hiyerarşik yapıdan bağımsız bir şekilde daha esnek katıımına yardımcı olmaktadır. Bundan dolayı öğrencilerin matematik dersine katıım istekleri artmış aynı zamanda olumlu duyuşsal, bilişsel ve davranış özelliklerini derse yansıtmışlardır. Matematik dersi birçok öğrencinin öğrenmede güçlük yaşadığı öğrenme alanı olduğu için bu zorluğun üstesinden gelmede ters yüz öğrenme modeli etkili bir çıkış yolu olabilir. Bu model sayesinde öğretmenler sınıf içi zamanı daha etkili bir şekilde kullanarak konuların daha iyi anlaşılmasına destek sağlayabilir (Fulton, 2012). Tüm bu anlatımların yanı sıra modelin matematik öğretimindeki etkinliğini artırmak için birtakım varsayımları göz önünde bulundurmak gerekir. Örneğin videoların öğrencilerin yaparak yaşayarak öğreneceği şekilde planlanmasına, kısa ve öz hazırlanmasına özen gösterilmelidir (Karaca ve Ocak, 2017). Matematik soyut kavramların sıklıkla kullanıldığı bir öğrenme alanı olduğundan ters yüz modelde öğretmen rehberliği son derece önemlidir. Özellikle dersin kuramsal kısımlarının etkileşimli video ortamında öğrenilmeye çalışımasında öğrenciler zorluk yaşayabilir. Bu durumun bilincine sahip bir öğretim programının iyi 
planlanması ve işletilmesi gerekir. Aksi halde öğrencilerde karmaşık öğrenme durumlarına ya da duyuşsal dalgalanmalara neden olabilir. Çünkü ters yüz modelinin öğrenmeye olumlu etkilerinin yanı sıra alanyazında ters yüz öğrenme modelinin öğrencilerin akademik başarısında artışa neden olmadığı ayrıca ders videolarını anlamakta zorlandıkları yönünde araştırma bulguları da yer almaktadır (Ford, 2015; Guerrore ve diğer., 2015; Johnson ve Renner, 2012; Yavuz, 2016).

Tüm anlatımlara ek olarak, çalışmanın belirli sınırlılıkları da bulunmaktadır. Örneğin çalışma 6 hafta ile sınırlı tutulmuştur. Bu yüzden daha geniş ölçekli ve birkaç üniteyi kapsayacak bir öğretim uygulamasının yapılması daha etkili sonuçlar verebilir. Çalışmanın bir diğer sınırlılı̆̆ı ise ters yüz öğrenme modelinin teknolojik araç, donanım ve internet altyapısı için maliyet gerektirmesidir. Sosyo-ekonomik durumu iyi olmayan öğrencilerde bu durumun olumsuz etkilerin oluşmaması için özen gösterilmesi gerekir. Sonuç olarak, bilgiye ulaşmada öğrenciyi merkeze alan ters yüz öğrenme modeli öğrencilerin matematiğe yönelik katılımlarına yönelik olumlu etki oluşturmada iyi bir öğrenme enstrümanı olarak kullanılabilir.

\section{1 Öneriler}

- Çalışmada kullanılan Edpuzzle öğrenme platformu ters yüz öğrenme modelinin etkili bir şekilde gerçekleştirilmesi için uygun teknik araçlar sunmaktadır. Bu özelliğinden dolayı videoların ders materyalleri olarak kullanıldığı bir yönetim sistemi olarak bilinmektedir. Bu doğrultuda öğrenme platformunun etkinliği farklı öğretim kademelerinde de araştırılabilir.

- Çalışmada maliyet, zaman, uygunluk, profesyonellik, içerik ve ulaşılabilirlik bileşenleri açısından Okulistik ders yazılımları tercih edilmiştir. Farklı ders yazılımları ya da uygulayıcılar tarafından hazırlanacak ders videolarıyla öğrencilerin matematik dersine olan katılımının derecesi tekrardan araştırılabilir.

- Günümüzde birçok ulus için ezberleyici öğrenme yerine yapısalcı öğrenme ön planda tutulmaktadır. Bu bakımdan ters yüz öğrenme modeli farklı öğrenme biçimlerine de kapı aralayarak öğrencilerin merkezde olduğu bir öğrenme anlayışına fırsat tanıyabilir.

- Ters yüz öğrenme modeli daha çok öğrenci intiyaçlarına dönük bir model olarak bilinse de ebeveynlerin, eğitimcilerin, öğreticilerin ve eğitim kurumlarının da model hakkındaki görüşleri incelenebilir.

- Ters yüz öğrenme modelinin verimli yürütülebilmesi için öğrencilerin, öğreticilerin hatta ebeveynlerin bilgilendirilmesi ile teknik araç ve donanım eksikliklerinin titizlikle takip edilmesi gerekir. Bu bakımdan araştırmacılar iyi bir öğretim planı hazırlamalıdır.

Benzer çalışmaya ek olarak, öğrencilerin bilgi ve beceri düzeylerini de ortaya çıkarabilecek şekilde dizayn edilmiş bir ters yüz öğrenme konseptinin oluşturulması alana değerli katkılar sağlayabilir.

\section{Kaynakça}

Adams, C. ve Dove, A. (2018). Calculus students flipped out: The impact of flipped learning on calculus students' achievement and perceptions of learning. PRIMUS, 28(6), 600-615.

Aksu, G. ve Güzeller, C. O. (2016). PISA 2012 matematik okuryazarlığı puanlarının karar ağacı yöntemiyle sınıflandırılması: Türkiye örneklemi. Eğitim ve Bilim, 41(185), 101-122.

Ayçiçek, B. ve Yelken, T. Y. (2017). The effect of flipped classroom model on students' classroom engagement in teaching English. International Journal of Instruction, 11(2), 385-398.

Aydın, B. (2016). Ters yüz sınıf modelinin akademik başarı, ödev/görev stres düzeyi ve öğrenme transferi üzerindeki etkisi. Yayınlanmamış yüksek lisans tezi, Süleyman Demirel Üniversitesi, Eğitim Bilimler Enstitüsü, Isparta.

Bergmann, J. ve Sams, A. (2012). Flip your classroom: Reach every student in every class every day. Washington: International Society for Technology in Education. https://www.liceopalmieri.gov.it/wpcontent/uploads/2016/11/FlipYourClassroom.pdf adresinden 18.06.2018 tarihinde erişilmiştir. 
Bolat, Y. (2016). Ters yüz edilmiş sınıflar ve eğitim bilişim ağı (EBA). Journal of Human Sciences, 13(2), 3373-3388.

Can, A. (2016). SPSS ile Bilimsel araştırma sürecinde nicel veri analizi (4. Baskı). Ankara: Pegem Akademi.

Çakır, E. (2017). Ters yüz sınıf uygulamalarının fen bilimleri 7. sınıf öğrencilerinin akademik başarı, zihinsel risk alma ve bilgisayarca düşünme becerileri üzerine etkisi. Yayınlanmamış yüksek lisans tezi, Ondokuz Mayıs Üniversitesi, Eğitim Bilimler Enstitüsü, Samsun.

Ford, P. (2015). Flipping a math content course for pre-service elementary school teachers. PRIMUS, 25(4), 369-380.

Fulton, K. (2012). Upside down and inside out: Flip your classroom to improve student learning. Learning \& Leading with Technology, 39(8), 12-17.

Gençer, B. G. (2015). Okullarda ters yüz sınıf modelinin uygulanmasına yönelik bir vaka çalışması. Yayınlanmamış yüksek lisans tezi, Bahçeşehir Üniversitesi, Eğitim Bilimler Enstitüsü, İstanbul.

George, D. ve Mallery, P. (2003). SPSS for Windows step by step: A simple guide and reference (11.0 Update). Boston: Allyn and Bacon.

Görü-Doğan, T. (2015). Sosyal medyanın öğrenme süreçlerinde kullanımı: Ters-yüz edilmiş öğrenme yaklaşımına ilişkin öğrenen görüşleri. Açıköğretim Uygulamaları ve Araştırmaları Dergisi, $1(2), 24-48$.

Grover, K. ve Stovall, S. (2013). Student-centered teaching through experiential learning and its assessment. NACTA Journal, 57(2), 86-87.

Guerrero, S., Beal, M., Lamb, C., Sonderegger, D. ve Baumgartel, D. (2015). Flipping undergraduate finite mathematics: Findings and implications. PRIMUS, 25(9-10), 814-832.

Güç, F. (2017). Rasyonel sayılar ve rasyonel sayılarda işlemler konusunda ters yüz sınıf uygulamasının etkisi. Yayınlanmamış yüksek lisans tezi, Amasya Üniversitesi, Fen Bilimleri Enstitüsü, Amasya.

İitoğlu, O. (2018). The impact of flipped classroom model on EFL learners' academic achievement, attitudes and self-efficacy beliefs: A mixed method study. Unpublished doctoral dissertation, Yıldız Technical University, Graduate School of Social Sciences, İstanbul.

Johnson, L. W. ve Renner, J. D. (2012). Effect of the flipped classroom model on a secondary computer applications course: Student and teacher perceptions, questions and student achievement. Unpublished doctoral dissertation, University of Louisville, Louisville.

Karaca, C. ve Ocak, M. A. (2017). Algoritma ve programlama eğitiminde ters yüz öğrenmenin üniversite öğrencilerinin akademik başarısına etkisi. International Online Journal of Educational Sciences, 9(2), 527-543.

Karasar, N. (2013). Bilimsel araştırma yöntemi (25. Baskı). Ankara: Nobel Akademik.

LaFee, S. (2013). Flipped learning. Education Digest, 79(3), 13-18.

Lo, C. K., Lie, C. W. ve Hew, K. F. (2018). Applying "first principles of instruction" as a design theory of the flipped classroom: Findings from a collective study of four secondary school subjects. Computers \& Education, 118, 150-165.

Love, B., Hodge, A., Grandgenett, N. ve Swift, A. W. (2014). Student learning and perceptions in a flipped linear algebra course. International Journal of Mathematical Education in Science and Technology, 45(3), 317-324.

Marlowe, C. (2012). The effect of the flipped classroom on student achievement and stres. Unpublished master's thesis, Montana State University, Bozeman, Montana. http://scholarworks.montana.edu/xmlui/handle/1/179 adresinden 05.06.2018 tarihinde erişilmiştir.

Miller, A. (2012). Five best practices for the flipped classroom. Edutopia. Posted Online, 24, 02-12. 
Milli Eğitim Bakanlığı (MEB) (2011). PISA Türkiye. Ankara: Milli Eğitim Bakanlığı Yenilik ve Eğitim Teknolojileri Genel Müdürlüğü. http://pisa.meb.gov.tr/wpcontent/uploads/2013/07/PISAkitab\%-C4\%B1.pdf. adresinden 01.04.2018 tarihinde erişilmiştir.

Milli Eğitim Bakanlığı (MEB) (2018). Matematik dersi öğretim programı (ilkokul ve Ortaokul 1, 2, 3, 4, 5, 6, 7 ve 8. Siniflar). Ankara. http://mufredat.meb.gov.tr/Default.-aspx adresinden 05.01.2018 tarihinde erişilmiştir.

Moravec, M., Williams, A., Aguilar-Roca, N. ve O'Dowd, D. K. (2010). Learn before lecture: a strategy that improves learning outcomes in a large introductory biology class. CBE Life Sciences Education, 9(4), 473-481.

Muir, T. (2017). Flipping the mathematics classroom: affordances and motivating factors. The Mathematics Educator, 17(1\&2), 105-130.

National Council of Teachers of Mathematics (NCTM) (2006). Curriculum focal points for prekindergarten through grade 8 mathematics: A quest for coherence. Reston, VA: Author.

National Council of Teachers of Mathematics (NCTM) (2000). Principles and standards for school mathematics. Reston, VA: Author.

Organisation for Economic Co-operation and Development (OECD) (2016). PISA 2015 results in focus. OECD, Paris.

Özdemir, A. (2016). Ortaokul matematik öğretiminde harmanlanmış öğrenme odaklı ters yüz sınıf modeli uygulaması. Yayınlanmamış doktora tezi, Gazi Üniversitesi, Eğitim Bilimler Enstitüsü, Ankara.

Sams, A. ve Bergmann, J. (2013). Flip your students' learning. Educational Leadership, 70(6), 16-20.

Sever, M. (2014). Derse katılım envanterinin Türk kültürüne uyarlanması. Eğitim ve Bilim, 39(176), 171-182.

Strayer, J. F. (2012). How learning in an inverted classroom influences cooperation, innovation, and task orientation. Learning Environment Research, 15, 171-193.

Talbert, R. (2012). Inverted classroom. Colleagues, 9(1), 1-2. http://scholarworks.gvsu.edu/colleagues/vol9/iss1/7 adresinden 10.06.2018 tarihinde erişilmiştir.

Trends in International Mathematics and Science Study (TIMSS) (2016). Highlights from TIMSS and TIMSS advanced 2015. https://nces.ed.gov/timss/timss2015/ adresinden 05.06.2018 tarihinde erişilmiştir.

Turan, Z. (2015). Ters yüz sınıf yönteminin değerlendirilmesi ve akademik başarı, bilişsel yük ve motivasyona etkisinin incelenmesi. Yayınlanmamış doktora tezi, Atatürk Üniversitesi, Eğitim Bilimler Enstitüsü, Erzurum.

Turan, Z. ve Göktaş, Y. (2015). Yükseköğretimde yeni bir yaklaşım: Öğrencilerin ters yüz sınıf yöntemine ilişkin görüşleri. Yükseköğretim ve Bilim Dergisi, 5(2), 156-164.

URL-1: http://www.okulistik.com/teacher/landing.php [Erişim Tarihi: 15.02.2018].

URL-2: https://edpuzzle.com/ [Erişim Tarihi: 15.02.2018].

Wang, Z., Bergin, C. ve Bergin, D. A. (2014). Measuring engagement in fourth to twelfth grade classrooms: The classroom engagement inventory. School Psychology Quarterly, 29(4), 517-535.

Yavuz, M. (2016). Ortaöğretim düzeyinde ters yüz sınıf uygulamalarının akademik başarı üzerine etkisi ve öğrenci deneyimlerinin incelenmesi. Yayınlanmamış yüksek lisans tezi, Atatürk Üniversitesi, Eğitim Bilimler Enstitüsü, Erzurum.

Zappe, S., Leicht, R., Messner, J., Litzinger, T. ve Lee, H. W. (2009). Flipping the classroom to explore active learning in a large undergraduate course. Paper presented at ASEE 2009 Conference, Austin, TX. https://peer.asee.org/flipping-the-classroom-to-explore-activel-earning-in-a-largeundergraduate-course.pdf. adresinden 15.06.2018 tarihinde erişilmiştir. 


\section{Extended Summary}

With the rapid spread of the use areas of technological tools and equipment, the star of the flipped learning model has become increasingly shiny and many places are often preferred. Flipped learning approach is widely known and used around the world. However, in some countries, the opposite is happening. However, the flipped learning model has been updated with the increase of web-based interactive learning platforms, online video sites, and open education resources. Therefore, with the flipped learning model, students can easily carry out information access activities in appropriate time periods and take place at the center of the classroom engagement. The aim of this study is to examine the effect of the flipped classroom model on students' classroom engagement in teaching mathematics. In this context following questions investigated:

1. Is there a significant difference between pre-test scores of classroom engagement inventory dimensions of experiment and control group?

2. Is there a significant difference between pre-test and post-test scores of the classroom engagement inventory dimensions of the experimental group?

3. Is there a significant difference between pre-test and post-test scores of the classroom engagement inventory dimensions of the control group?

4. Is there a significant difference between pre-test and post-test scores of classroom engagement inventory dimensions of experiment and control group?

A total of 36 students participated in the study, which was a quasi-experimental design, 18 in experiments, and 18 in control groups. Classroom Engagement Inventory was used as a data collection tool. An experimental study was carried out for 6 weeks except for pilot application. The videos suitable for the lesson acquisition obtained from the Okulistik learning platform were uploaded to the Edpuzzle platform and made interactive. In the analysis of the data, a descriptive statistical technique as well as normality analyzes, independent samples t-Test, Mann-Whitney U and Wilcoxon Signed Rank tests were performed. When the findings are evaluated in general, the flipped learning model provides more active participation of the students in a mathematics lesson. The flipped learning model, which is seen as one of the blended learning methods, helps the students to participate more flexible in the mathematics lessons independently of the hierarchical structure. As a result, the students' desire to participate in mathematics lessons increased and they reflected positive affective, cognitive and behavioral characteristics. The Edpuzzle learning platform used in the study offers appropriate technical tools for effective implementation of the flipped learning model. Because of this feature, it is known as a management system where videos are used as lesson material. In this context, the effectiveness of this learning platform can be explored in different teaching fields and stages. In terms of cost, time, eligibility, professionalism, content and accessibility components, Okulistik lesson software has been preferred. With different lesson software, the degree of engagement of students in mathematics can be investigated. 